\title{
EFEKTIVITAS KOMUNIKASI INTERPERSONAL DALAM MEWUJUDKAN KEHARMONISAN KELUARGA DI MASYARAKAT NELAYAN MESKOM BENGKALIS
}

\author{
Arwan \\ Fakultas Dakwah dan Komunikasi,UIN Suska Riau \\ Jl. HR Soebrantas Km 15 Simpangbaru, Tampan, Pekanbaru 28293 \\ Email: arwanmasud66@gmail.com
}

\begin{abstract}
Abstrak
Keluarga yang tentram, bahagia, dan sejahtera merupakan dambaan setiap manusia. Hal ini membutuhkan komunikasi yang dapat membuat pasangan suami istri langgeng dan harmonis. Karena kunci kelanggengan perkawinan adalah keberhasilan melakukan penyesuaian di antara pasangan. Namun pada kenyataannya, kebahagiaan suatu perkawinan tidak hanya terletak pada faktor cinta saja karena ada salah satu faktor yang lebih penting bila dibandingkan dengan faktor cinta yaitu komunikasi interpersonal antara pasangan suami istri. Dari uraian tersebut, peneliti tertarik mengkaji mengenai keharmonisan keluarga dalam sebuah penelitian ilmiah tentang efektivitas komunikasi interpersonal dalam mewujudkan keharmonisan keluarga di masyarakat nelayan Meskom Bengkalis. Hasil penelitian menemukan bahwa Untuk mewujudkan keharmonisan dalam kehidupan keluarga, masyarakat nelayan di desa Meskom berusaha meciptakan sebuah komuikasi dalam kehidupan keluarganya yaitu antara suami,isteri dan anak-anak. Selanjutnya adanya kepercayaan penuh pada masing-masing pasangan di masyarakat nelayan ini karena merasa merasa senasib sepenanggungan. Dalam tradisi Melayu ada petuah "berat sama dipikul dan ringan dijinjing”. Dalam tradisi Melayu masing orang dalam keluarga saling bantu membantu satu sama lainnya terutama dalam satu keluarga.
\end{abstract}

Kata kunci: Efektivitas komunikasi, keharmonisan keluarga, nelayan, Meskom, Bengkalis

\section{PENDAHULUAN}

\section{A. Latar Belakang}

Manusia dalam perkembangannya memiliki berbagai kebutuhan-kebutuhan yang harus terpenuhi. Kebutuhan-kebutuhan tersebut yakni makan, minum, penghargaan, dan lain sebagainya termasuk salah satunya yakni kebutuhan akan pasangan hidup. Pasangan hidup yang dimaksud adalah mampu menemani keberlangsungan hidup manusia dalam sebuah ikatan pernikahan. Pernikahan yang dinilai sebagai langkah awal pertemuannya seorang pria dan wanita yang diikat dengan perjanjian suci untuk membentuk sebuah keluarga bahagia (dalam Shaleh, 2008:298).

Melalui pernikahan manusia berharap mampu memenuhi kebutuhan hidupnya tersebut bersama orang yang dicintainya dalam bahtera rumah tangga untuk menjadi keluarga yang harmonis. Yaitu kehidupan keluarga yang saling mengasihi, melengkapi, serta sikap saling mendukung di saat masa-masa sulit.

Keluarga yang tentram, bahagia, dan sejahtera merupakan dambaan setiap manusia. Untuk mewujudkan keluarga sebagaimana yang didambakan merupakan usaha yang tidak mudah, karena terbentuknya keluarga merupakan sebuah proses yang panjang dan 
melalui penyesuaian yang tidak mudah, mengingat keluarga terbentuk dari dua kepribadian yang berasal dari keluarga yang berbeda, memiliki latar belakang dan pengalaman hidup yang berbeda pula. Perbedaan-perbedaan tersebut sering kali menjadi pemicu terjadinya kesalahan pahaman.

Hal ini dibutuhkan komunikasi yang dapat membuat pasangan suami istri langgeng dan dan harmonis. Karena kunci kelanggengan perkawinan adalah keberhasilan melakukan penyesuaian diantara pasangan. Penyesuaian yang dimaksud adalah bersifat dinamis dan memerlukan sikap serta cara berpikir yang luwes. Menurut peneliti hal ini dapat diwujudkan salah satunya dengan komunikasi.

Komunikasi merupakan aspek yang paling penting, karena berkaitan dengan hampir semua aspek dalam kehidupan manusia termasuk dalam hubungan berpasangan. Hasil dari semua diskusi dan pengambilan keputusan dikeluarga, yang mencakup keuangan, anak, karier, agama bahkan dalam setiap pengungkapan perasaan, hasrat, dan kebutuhan akan tergantung pada gaya, pola, dan keterampilan berkomunikasi. Keterampilan dalam berkomunikasi dapat terwujud dalam kecermatan memilih kata yang digunakan dalam menyampaikan gagasan pada pasangan (Lestari, 2012 : 11).

Pada era globalisasi ini, banyak orang berpendapat bahwa kebahagiaan suatu perkawinan terletak pada hubungan biologis antara pria dan wanita yang menitikberatkan pada faktor cinta (Sholeh 2008:297). Namun pada kenyataannya, kebahagiaan suatu perkawinan tidak hanya terletak pada faktor cinta saja karena ada salah satu faktor yang lebih penting bila dibandingkan dengan faktor cinta yaitu komunikasi interpersonal antara pasangan suami istri.

Hal ini terbukti dengan banyaknya angka perceraian yang terjadi bukan karena tidak terwujudnya kebahagiaan melalui hubungan biologis tetapi ada faktor yang lain yang menjadi pemicu termasuk salah satunya komunikasi. Bedasarkan data dari Badan Urusan Pengadilan Agama (BADILAG) Mahkamah Agung (MA) angka perceraian di indonesia dari tahun 2005 hingga 2010 meningkat hingga 70 persen. Pada tahun 2010, terjadi 285.184 perceraian diseluruh indonesia. Penyebab pisahnya pasangan jika diurutkan tiga besar paling banyak akibat faktor ketidakharmonisan sebanyak 91.841 perkara, tidak ada tanggungjawab 78.407 perkara, dan masalah ekonomi 67.891 perkara.

Sedangkan tahun sebelumnya, tingkat perceraian nasional masih di angka 216.286 perkara. Angka faktor penyebabnya terdiri atas ketidakharmonisan 72.274 perkara, tidak ada tanggungjawab 61.128 perkara, dan faktor ekonomi 43.309 perkara (Republika, 12 Januari 2014).

Untuk di Bengkalis angka perceraian tidaklah sedikit. Berdasarkan data awal yang penulis jajaki, angka perceraian tahun 2013 tercatat 210 cerai gugat dan 150 cerai talak. Artinya jumlah yang cerai di Bengkalis mencapai 360 orang.

Bengkalis khususnya Kecamatan Bengkalis merupakan Ibu Kota Kabupaten kemajuann sudah semakin pesat. Berbagai pasilitas untuk menunjang kemaslahatan masyarakat sudah sangat memadai, Jalan yang menghubungkan antar desa dan kota sudah lancar. Pusat perbelanjaan seperti pasar tradisional dan swalayan juga sudah sangat memadai.

Semakin berkembang daerah ini maka semakin berkembang pula pola pikir dan gaya hidup masyarakat. Berdasarkan observasi sementara yang dilakukan peneliti dikelurahan ini terlihat kurangnya keharmonisan diantara suami istri. Dimana seringnya terjadi perselingkuhan, seringnya terjadi pertengkaran yang diakibat kurangnya ekonomi, atau suami istri yang sibuk bekerja sehingga tidak ada waktu untuk melakukan kewajiban-kewajiban antara suami istri sehingga menuntut hak 
masing-masing sehingga terjadi perceraian.

Menurut peneliti angka perceraian dan ketidakharmonisan dapat diminimalisir dengan komunikasi yang dilakukan oleh suami-istri secara personal. Dimana Komunikasi interpersonal dapat didefenisikan sebagai komunikasi antara orang-orang secara tatap muka, yang memungkinkan setiap pesertanya menangkap reaksi orang lain secara langsung, baik secara verbal maupun nonverbal (dalam Rubani, 2011:175). Artinya bahwa adanya pertukaran informasi dan interaksi yang intim antara pasangan suami istri juga seluruh keluarga.

Namun, interaksi ini tidak hanya dilakukan dengan menggunakan verbal saja. Tetapi perlu adanya simbol-simbol atau sinyalsinyal lainnya yang diwujudkan dalam perlakuan bahasa tubuh atau nonverbal. Kata cinta saja tidaklah cukup dijadikan sebagai patokan untuk mengungkapkan perasaan. Namun perlu juga diiringi sebuah perhatian, sentuhan, serta simbol-simbol lain untuk mencurahkan kasih sayang karena hubungan akrab ditandai oleh kadar yang tinggi mengenai keramahtamahan dan kasih sayang, kepercayaan, pengungkapan diri, dirumuskan melalui lambang-lambang dan ritual (Budyatna \& Ganiem, 2011: 15).

Dari uraian latar belakang tersebut, peneliti tertarik untuk mengkaji mengenai keharmonisan keluarga dalam sebuah penelitian ilmiah dengan judul "Efektivitas Komunikasi Interpersonal Dalam Mewujudkan Keharmonisan Keluarga di Masyrakat Nelayan Meskom Bengkalis.”

\section{B. Permasalahan}

\section{Identifikasi Masalah}

Dari pendahuluan diatas dapatlah permasalahan-permasalahan sebagai berikut :

a. Kesibukkan antara suami istri sehingga tak ada waktu untuk saling berkomunikasi

b. Kurangnya keharmonisan antara suami istri c. Adanya faktor kekurangan ekonomi

d. Sering terjadinya perselingkuhan

\section{Batasan Masalah}

Untuk lebih terarahnya penulisan ini maka penulis akan memberikan pembatasan yang akan diteliti yaitu "Efektivitas Komunikasi Interpersonal Dalam Mewujudkan Keharmonisan Keluarga Di Marakat Nelayan Meskom Bengkalis.”

\section{Rumusan Masalah}

Berdasarkan uraian dari latar belakang, maka rumusan masalah yang diajukan pada penelitian ini adalah "Apakah komunikasi interpersonal efektif dalam mewujudkan keharmonisan Keluarga dan Faktor-faktor apa saja yang mempegaruhinya?"

\section{A. Tujuan Penelitian}

Tujuan dari penelitian ini yakni untuk mengetahui Efektivitas Komunikasi Interpersonal dalam Mewujudkan Keharmonisan Keluarga di Masyarakat Nelayan Meskom Bengkalis.

\section{Manfaat penelitian}

1. Kegunaan teoritis

Sebagai pengembangan keilmuan akademisi khususnya pada bidang ilmu komunikasi.

2. Kegunaan praktis

Diharapkan dapat memberikan sumbangan yang nyata bagi berbagai kehidupan masyarakat untuk lebih menghidupkan suasana komunikasi secara personal antara pasangan keluarga, agar dapat menjadi keluarga yang harmonis.

\section{KERANGKA TEORETIS DAN KONSEP OPERASIONAL}

\section{A. Kerangka Teoritis}

Agar penulisan ini terarah, maka peneliti akan menggunakan teori yang bersangkut dengan yang peneliti bahas. Sebagai 
dasar pandangan dalam penelitian ini maka penilis akan menggunakan teori self disclosure atau proses pengungkapan diri yang telah lama menjadi fokus penelitian dan teori komunikasi mengenai hubungan, merupakan proses mengungkapkan informasi pribadi kita kepada orang lain dan sebaliknya.

Sidney Jourard menandai sehat atau tidaknya komunikasi antar pribadi dengan melihat keterbukaan yang terjadi dalam komunikasi. Mengungkapkan yang sebenarnya mengenai diri kita kepada orang lain yang juga bersedia mengungkapkan yang sebenarnya tentang dirinya, dipandang sebagai ukuran dari hubungan yang ideal.

Ahli lain Joseph Luft (Reardon,1987:163) mengemukakan teori self disclosure yang didasarkan pada model interaksi manusia, yang disebut Johari Window. Menurut Luft, orang memiliki atribut yang hanya diketahui oleh dirinya sendiri, hanya diketahui oleh orang lain, diketahui oleh dirinya sendiri dan orang lain dan tidak diketahui oleh siapapun. Jenis-jenis pengetahuan ini menunjuk pada keempat kuadran dari Johari Window. Idealnya, kuadran satu yang mencerminkan keterbukaan akan semakin membesar atau meningkat.

Jika komunikasi antara dua orang berlangsung dengan baik, maka akan terjadi disclosure yang mendorong informasi mengenai diri masing-masing kedalam kuadran "terbuka". Kuadaran 4 sulit untuk diketahui, tetapi mungkin dapat dicapai melalui kegiatan seperti refleksi diri dan mimpi.

Meskipun self-disclosure mendorong adanya keterbukaan, namun keterbukaan sendiri ada batasnya. Artinya perlu kita pertimbangkan kembali apakah menceritakan segala sesuatu tentang diri kita kepada orang lain akan menghasilkan efek positif bagi diri kita dengan orang tersebut. Bebrapa penelitian menunjukan bahwa keterbukaan yang ekstrim akan memberikan efek negatif bagi hubungan.
Teori ini dapat diaplikasikan dalam membina hubungan suami istri. Dengan adanya pengungkapan diri dari masing-masing individu (suami atau istri) maka kebersamaan akan timbul dan setiap konflik yang dialami dapat dilalui dengan baik. Pasangan suami istri pun dapat mengaplikasikan konsep Johari Window dalam upaya membina hubungan baik dengan pasangannya. Dengan Johari Window ini, masing-masing individu dapat memahami dan dipahami oleh pasangannya.

Banyak faktor yang mempengaruhi jumlah, jenis dan kualitas hubungan. Misalnya status sosial ekonomi, umur, dan gender (jenis kelamin) akan mempengaruhi bukan saja kepada siapa seseorang berhubungan, tetapi juga bagaimana dan seberapa sering orang tersebut berinteraksi dengan orang lain. Orang yang memiliki status ekonomi yang berbeda akan meyebabkan peerbedaan sumber-sumber yang dimiliki untuk mengembangkan hubungan.

Selain faktor sosial ekonomi, faktor usia pun mempengaruhi terbinanya sebuah hubungan atau relasi. Menurunnya kesehatan dan mobilitas membuat mereka agak sulit melakukan sosialisasi. Selain itu, pasangan pengantin baru dan pasangan suami istri yang sudah menikah selama puluhan tahun akan memaknai hubungan mereka secara berbeda. Maka dari itu dibutuhkan saling pengertian agar setiap pasangan dapat menerima hal-hal yang berbeda dari pasangannya.

Gender tidak kalah pentingnya dengan faktor yang sudah disebutkan sebelumnya. Perbedaan jenis kelamin akan berpengaruh pada perilaku setiap individu dan juga sudah pasti berpengaruh pada pola komunikasinya. Pasangan suami istri adalah pasangan antara laki-laki dan perempuan, di mana terdapat banyak perbedaan di dalam dirinya yang sudah kodrati. Wanita dianggap lebih banyak berbicara sekedar untuk berbicara, bila dibandingkan dengan pria. Wanita lebih banyak terlibat dalam pembicaraan yang bersifat 
pribadi, dan pada umumnya juga wanita lebih menaruh perhatian pada kualitas interaksi atau hubungan.

Dengan komunikasi yang terbuka antara pasangan suami istri, maka akan terbina saling pengertian, mana-mana yang baik perlu dipertahankan dan dikembangkan, dan manamana yang tidak baik perlu dihindarkan. Dengan demikian akan terbentuklah sikap saling terbuka, saling mengisi, saling mengerti dan akan terhindar dari kesalah pahaman. Komunikasi yang terjadi antara suami istri membuat keduanya saling berbagi dalam hal yang rahasia dengan bercerita juga melakukan segala sesuatu secara bersama atau saling mempengaruhi.

\section{Efektivitas Komunikasi Interpersonal}

Komunikasi interpersonal merupakan aktivitas yang dilakukan sehari-hari, dan merupakan cara untuk menyampaikan dan menerima pikiran, informasi, gagasan, perasaan serta emosi antara dua orang termasuk suami istri.

Menurut Effendi, pada hakekatnya komunikasi interpersonal adalah komunikasi antar komunikator dengan komunikan, komunikasi jenis ini dianggap paling efektif dalam upaya mengubah sikap, pendapat atau perilaku seseorang, karena sifatnya dialogis berupa percakapan. Arus balik bersifat langsung, komunikator mengetahui tanggapan komunikan pada saat itu juga. Pada saat komunikasi dilancarkan, komunikator mengetahui pasti apakah komunikasinya positif atau negatif, berhasil atau tidaknya. Jika ia dapat memberi kesempatan pada komunikan untuk seluas-luasnya (Rubani, 2011:175-176).

Suami istri berkomunikasi pastilah dengan bertatap muka dan dalam jarak/proksemik yang dekat atau intim. Dengan keintiman ini, maka diharapkan komunikasi yang berlangsung akan lebih efektif dan dapat menjadi dasar dari proses memahami kehidupan bersama. Suami istri akan memahami peran dan fungsinya masing-masing dalam keluarga. Mereka bisa saling melengkapi satu sama lain karena mereka selalu mengkomunikasikan segala hal yang sedang mereka rasakan atau pikirkan.

Aspek penting lainnya dalam komunikasi antar pribadi adalah adanya hubungan dua arah. Dalam hal ini perlunya keseimbangan antara dua pihak yang berkomunikasi, adanya timbal balik antara suami dan istri saat berkomunikasi akan terus mengakrabkan hubungan yang sedang terbina.

Menurut Rubani (2011) efektivitas komunikasi interpersonal dimulai dengan lima kualitas umum yang dipertimbangkan yaitu keterbukaan (openess), empati (empathy), sikap mendukung (supportiviness), sikap positif (positiveness), dan kesetaraan (equality). Kualitas umum yang menjadi pertimbangan efektivitas komunikasi interpersonal yakni:

\section{a) Keterbukaan (Openess)}

Kualitas keterbukaan mengacu pada sedikitnya tiga aspek dari komunikasi interpersonal. Pertama, komunikator interpersonal yang efektif harus terbuka kepada orang yang diajaknya berinteraksi. Aspek keterbukaan yang kedua mengacu kepada kesediaan komunikator untuk bereaksi jujur terhadap stimulus yang datang. Aspek ketiga menyangkut tentang "kepemilikan" perasaan dan pikiran. Terbuka dalam pengertian ini adalah mengakui milik kita dan kita mempertanggungjawab atasnya.

\section{b) Empati (Empathy)}

Henry backrack mendefenisikan empati sebagai kemampuan seseorang untuk mengetahui apa yang sedang dialami orang lain pada saat tertentu, dari sudut pandang orang lain itu, melalui kaca mata orang lain itu. Beda simpati dan empati. Bersimpati adalah merasakan bagi orang lain atau ikut merasa bersedih. Sedangkan berempati adalah 
merasakan sesuatu seperti orang yang mengalaminya.

Orang yang empatik mampu memahami motivasi dan pengalaman orang lain, perasaan dan sikap mereka, serta harapan dan keinginan mereka untuk masa mendatang. Kita dapat mengkomunikasikan empati baik secara verbal maupun secara non verbal. Secara nonverbal, kita dapat mengkomunikasikan empati dengan memperlihatkan :

1) Keterlibatan aktif dengan orang itu melalui ekspresi wajah dan gerak-gerik yang sesuai.

2) Kosentrasi terpusat meliputi kontak mata, postur tubuh yang penuh perhatian, dan kedekatan fisik.

3) Sentuhan atau belaian yang sepantasnya.

\section{c) Sikap mendukung}

Hubungan interpersonal yang efektif adalah hubungan dimana terdapat sikap mendukung (supportiveness). Komunikasi yang terbuka dan empatik tidak dapat berlangsung dalam suasana yang tidak mendukung. Kita memperlihatkan sikap (1) deskriptif, bukan evaluasi, (2) spontan, bukan strategis, dan (3) provisonal, bukan sangat yakin.

\section{d) Sikap positif (positiveness)}

Kita mengkomunikasikan sikap positif dalam komunikasi interpersonal dengan sedikitnya dua cara : (1) menyatakan sikap positif dan (2) secara positif mendorong orang yang menjadi teman kita berinteraksi. Sikap positif mengacu kepada sedikitnya dua aspek dari komunikasi interpersonal. Pertama, komunikan interpersonal terbina jika seseorang memilih sikap positif terhadap diri mereka sendiri. Kedua, perasaan positif untuk situasi komunikasi pada umumnya sangat penting untuk interaksi yang efektif. Tidak ada yang lebih menyenangkan daripada berkomunikasi dengan orang yang tidak menikmati interaksi atau tidak bereaksi secara menyenangkan terhadap situasi atau situasi atau suasana interaksi.

\section{e) Kesetaraan (Equality)}

Dalam setiap situasi, barangkali terjadi ketidaksetaraan, salah seorang mungkin lebih pandai, lebih kaya, lebih tampan atau cantik, atau lebih atletis daripada yang lain. Tidak pernah ada dua orang yang bener-bener setara dalam segala hal. Terlepas dari ketidaksetaraan ini, komunikasi interpersonal akan lebih efektif bila suasananya setara. Artinya, harus ada pengakuan secara diam-diam bahwa kedua pihak sama-sama bernilai dan berharga, bahwa kedua masing-masing pihak mempunyai sesuatu yang penting untuk disumbangkan. Dalam suatu hubungan interpersonal ditandai oleh kesetaraan, ketidaksependapatan dan konflik lebih dilihat sebagai upaya untuk memahami perbedaan. Kesetaraan tidak mengharuskan kita menerima dan menyetujui begitu saja perilaku verbal dan nonverbal pihak lain. Kesetaraan berarti kesetaraan meminta kita untuk memberikan "penghargaan positif tak bersyarat" kita orang lain (Rubani 2011:186).

Keefektivan komunikasi dapat pula dijelaskan dari perspektiv the 5 Inevitable laws of effective atau lima hukum komunikasi efektif (Aw, 2011: 80-82). Lima hukum tersebut diantaranya

\section{Respect}

Hukum pertama dalam mengembangkan komunikasi interpersonal yang efektif adalah respect, ialah sikap menghargai setiap individu yang menjadi sasaran pesan yang kita sampaikan.

\section{Empathy}

empati merupakan sikap atau kemampuan untuk menempatkan diri kita pada situasi simbol atau kondisi yang dihadapi oleh orang lain.

\section{Audible}

Makna dari Audible antara lain: dapat didengarkan dan dimengerti dengan baik.

\section{Clarity}

Adanya sikap terbuka dan transparansi. Dalam komunikasi interpersonal kita perlu 
mengembangan sikap terbuka sehingga kita dapat menimbulkan kepercayaan dari komunikan.

\section{Humble}

Hukum ke lima membangun komunikasi interpersonal yang efektif adalah sikap rendah hati. Rendah hati pada intinya: sikap melayani, sikap menghargai, mendengarkan dan menerima kritik serta berani mengakui kesalahan.

Lebih lanjut lagi Aw (2011:85-86) menjelaskan ada beberapa faktor kefektifannya. Pertama, faktor keberhasilan dilihat dari sudut pandang komunikator dimana komunikator harus memiliki kredibilitas yang tinggi, daya tarik, kemampuan intelektual serta integritas sehingga dapat memberikan pengaruh terhadap sipenerima pesan. Kedua, faktor keberhasilan dilihat dari sudut komunikan. Dimana komunikan bersifat ramah, bersahabat serta memiliki pengetahuan yang luas sehingga cepat menerima informasi yang diberikan oleh komunikator. Ketiga, faktor keberhasilan dilihat dari sudut pesan. Dimana pesan harus disampaikan secara jelas dan tidak menimbulkan multi interpretasi atau penafsiran yang berlainan.

Menurut stewart dan Sylvia (Mulyana, 2001:23-27) ada lima hal yang dapat dijadikan ukuran bagi komunikasi yang efektif adalah pemahaman, kesenangan, mempengaruhi sikap, memperbaiki hubungan, dan tindakan.

\section{Keharmonisan Keluarga}

\section{1) Pengertian keharmonisan suami istri}

Secara terminologi keharmonisan berasal dari kata harmonis yang berarti selaras. Titik berat dari keharmonisan adalah keadaan selaras atau serasi, keserasian bertujuan untuk mencapai keselarasan dan keserasian. Dalam kehidupan, keluarga perlu menjaga kedua hal tersebut untuk mencapai keharmonisan (Tim Penyusunan Kamus Bahasa Indonesia, 1989:299).
Keluarga bahagia menurut Hurlock (1980:299) adalah Pasangan suami istri yang memperoleh kebahagiaan bersama dan membuahkan keputusan yang diperoleh dari peran yang mereka mainkan bersama, mempunyai cinta yang matang dan mantap satu sama lain, dan dapat melakukan penyesuaian seksual dengan baik, serta dapat menerima peran sebagai orang tua.

Menjadi keluarga yang harmonis dan bahagia merupakan impian serta cita-cita bagi setiap pasangan yang telah menikah. Menjalin hubungan dengan penuh rasa cinta, kasih sayang, sikap suportif dan perhatian adalah esensi dalam sebuah keluarga.

Menurut Basri keluarga yang harmonis dan berkualitas yaitu keluarga yang rukun bahagia, tertib, displin, saling menghargai, penuh pemaaf, tolong menolong dalam kebajikan, memiliki etos kerja ynag baik, memanfaatkan waktu luang dengan hal positif dan mampu memenuhi dasar keluarga.

Pendapat senada juga dikemukakan oleh Qaimi (2002:14) yang mengatakan bahwa keluarga yang harmonis merupakan keluarga yang penuh ketenangan, ketentraman, kasih sayang, keturunan dan keberlangsungan generasi masyarakat, belas kasih dan pengorbanan, saling melengkapi, dan menyempurnakan, serta saling mampu dan bekerja sama.

\section{2) Faktor-Faktor Yang Mempengaruhi} Keharmonisan Keluarga

Seorang wanita dan pria bertemu dan disatukan dalam suatu ikatan pernikahan dengan tujuan untuk membina sebuah keluarga harmonis. Ada beberapa hal yang dapat mempengaruhi keaharmonisan keluarga. Karena keluarga harmonis dan bahagia merupakan tujuan yang penting, untuk itu perlu diperhatikan beberapa faktor yang dapat mempengaruhi nya diantara nya :

a) Perhatian, Yaitu menaruh hati pada seluruh anggota keluarga sebagai dasar utama hubungan yang baik antar anggota keluarga. 
Baik pada pada perkembangan keluarga dengan memperhatikan peristiwa dalam keluarga, dan mencari sebab akibat permasalahan, juga terdapat perubahan pada setiap anggotanya.

b) Pengetahuan, Perlunya menambah pengetahuan tanpa henti-hentinya untuk memperluas wawasan sangat dibutuhkan dalam menjalani kehidupan keluarga. Sangat perlu untuk mengetahui anggota keluarganya, yaitu setiap perubahan, dan perubahan dalam anggota keluarganya agar kejadian yang kurang diinginkan kelak diantisipasi.

c) Pengenalan terhadap semua anggota keluarga, Hal ini berarti pengenalan terhadap diri sendiri dan pengenalan diri sendiri yang baik penting untuk memupuk pengertian-pengertian.

d) Bila pengenalan diri sendiri telah tercapai maka akan lebih mudah menyoroti semua kejadian atau peristiwa yang terjadi dalam keluarga. Masalah akan lebih mudah diatasi, karena banyaknya latar belakang lebih cepat terungkap dan teratasi (Gunarsa, 1980:4244).

Dalam pernikahan, keberhasilan untuk memperoleh dan merasakan kesejahteraan serta kebahagiaan tergantung dari penyesuaianpenyesuaian yang biasa disebut adaptasi terhadap suami atau istri sendiri dan bagaimana mengatasi kesulitan-kesulitan dengan memperhatikan :

\section{1) Menghadapi kenyataan}

Dalam kebersamaan hidup dari hari ke hari, tahun demi tahun, banyak hal akan terungkap dan kenyataan-kenyataan akan tersingkap seperti kenyataan mengenai pribadi masing-masing, kenyataan mengenai pekerjaan atau kegiatan masing-masing, kenyataan yang mungkin disenangi, bahkan mungkin juga menjengkelkan.

Perlu menghadapi kenyataan hidup dan semua yang terungkap dan tersingkap, bersamasama sebagai suatu tim, dan menanggulangi bersama-sama dengan bijak akan menyelesaikan masalah hidup.

2) Penyesuaian yang timbal balik.

Dalam perjalanan pernikahan sering timbul permasalahan-permasalahan yang dapat mengakibatkan benturan emosional, sikap alergi terhadap masing-masing dan sikap masa bodoh. Akhirnya timbul keregangan antara mereka berdua yang mengarah kesuasana hambar dan dingin. Maka harus ada upaya berkesinambungan untuk saling memperhatikan, mengungkapkan cinta dengan sungguh-sungguh, menunjukkan pengertian, menghargai, saling memberikan dukungan dan semangat, yang semuanya berperan penting dalam memupuk hubungan yaang baik, juga pada hubungan yang paling intim.

3) Latar belakang suasana yang baik

Perlu suatu suasana yang dilatarbelakangi oleh pikiran-pikiran yang penuh cita kasih, untuk menciptakan suasana yang baik. Ada beberapa hal yang perlu diperhatikan:

a. Suami istri tidak kehilangan individualitasnya. Masing-masing harus tetap memiliki kepribadian, tanpa menjadi robot, dan tetap harus memberi arti dalam hubungan kesatuan.

b. Asas berbagi sama harus diterapkan seluas mungkin. Berbagi sama dalam hal pekerjaan, waktu luang, pemasukan, kewajiban, saling membant dan saling memberi pengertian.

c. Setiap tindakan dan keputusan yang penting harus dibahas bersama terlebih dahulu. Kebiasaan ini akan memelihara kepercayaan terhadap pasangan dan menjamin kerja sama (Gunarsa,2002:8-11)

Kunci utama keharmonisan sebenarnya terletak pada kesepahaman hidup suami dan istri. Karena kecilnya kesepahaman dan usaha untuk saling memahami ini akan membuat keluarga menjadi rapuh. Makin banyak perbedaan antara kedua belah pihak maka makin besar tuntuan pengorbanan dari kedua 
belah pihak. Jika salah satunya tidak mau berkorban maka pihak satunya harus mau berkorban. Jika pengorbanan tersebut telah melampaui batas tatu kerelaannya maka keluarga tersebut terancam. Maka fahamilah keadaan pasangan, baik kelebihan maupun kekurangannya yang kecil hingga yang terbesar untuk mengerti sebagai landasan dalam menjalani kehidupan berkeluarga (Qoriah 2009:62-85).

\section{B. Konsep Operasional}

Indikator-indikator yang menjadi tolak ukur dalam peneletian ini adalah sebagai berikut :

1. Efektivvitas Komunikasi Interpersonal Indikatornya :

a. Bentuk komunikasi

Suami istri saling bersenda gurau dengan pasangan

Suami istri saling berdiskusi

Suami istri saling tersenyum

b. Durasi

Waktu yang digunakan suami istri saat berkomunikasi.

\section{c. Pesan}

Suami istri mengungkapkan rasa sayang kepada suami istri.

2. Keharmonisan Keluarga

a. Saling Mengerti

Suami istri saling mengetahui kebiasaan suami istri

Suami istri mengetahui kesukaan suami istri

b. Saling Menerima

Suami istri menerima kelebihan dan kekurangan pasanganya

c. Saling Menghargai

Suami istri saling meminta pendapat saat memutuskan sesuatu

d. Saling Mempercayai

Suami istri memberikan kepercayaan penuh atas peran yg dijalanin masingmasing
Suami istri saling percaya mengenai perkataan pasangannya

e. Saling Mencintai

Suami istri memberikan motivasi kepada pasangan saat suami atau istri dihadapkan pada suatu masalah.

\section{METODE PENELITIAN}

\section{Jenis Penelitian}

Penelitian ini menggunakan pendekatan kwalitatif. dimana tujuannya adalah peneliti ingin mendeskripsikan fenomena yang terjadi dilapangan dan harus terjun kelapangan dan kebenarannya dapat dipertanggung jawabkan. Artinya data yang dikumpulkan menggunakan instrumen berupa wawancara lalu diolah dan dianalisis disecara kwalitatif dengan menggunakan deskriptif.

Menurut Sugiyono (2011:8) metode penelitian kuantitatif dapat diartikan sebagai metode penelitian yang berlandaskan pada filsafat positifisme, digunakan untuk meneliti populasi dan sampel tertentu, pengumpulan data menggunakan instrumen penelitian.

\section{Lokasi Penelitian}

Penelitian ini dilaksanakan di Lingkungan manyarakat Nelayan Meskom Kabupaten Bengkalis.

\section{Fokus Penelitian}

Fokus penelitian ini adalah efektivitas komunikasi interpersonal dalam mewujudkan keharmonisan keluarga di Masyarakat Desa Meskom Bengkalis, terutama pasangan suami istri yang tinggal di Lingkungan manyarakat Nelayan Meskom Bengkalis..

\section{Responden Penelitian}

Adapu yang mejadi responden dari penelitian ini adalah seluruh suami istri yang tinggal di Lingkungan masyarakat Nelayan Meskom Bengkalis yang berjumlah $350 \mathrm{KK}$. Teknik pengambilan sampel dengan menggunakan cluster sampling yaitu menentukan sampel dengan sumber data yang luas (Sugiyono, 2011:83) dengan signifikan eror $5 \%$ sehingga jumlah responden pada 
penelitian sebanyak 17 KK ditambah dengan Kepala dan aparat desa yang terkait.

\section{Teknik Pengumpulan Data}

Adapun teknik pengumpulan data yang digunakan dalam penelitian ini adalah :

\section{1) Observasi}

Dalam penelitian ini observasi dibutuhkan untuk dapat memahami proses terjadinya wawancara dan hasil wawancara dapat dipahami dalam konteksnya. Observasi yang akan dilakukan adalah observasi terhadap subjek, perilaku subjek selama wawancara, interaksi subjek dengan peneliti dan hal-hal yang dianggap relevan sehingga dapat memberikan data tambahan terhadap hasil wawancara.

2) Wawancara

Dalam penelitian ini, wawancara dilakukan untuk mengumpulkan data dari masyarakat Nelayan Di Meskom dengan menggunakan model deep interview yai wawancara secara mendalam terhapad responden penelitian

\section{3) Dokumentasi}

Metode dekumentasi adalah mencari data mengenai hal-hal atau variasi yang berupa catatan, transkrip, buku, surat kabar, majalah, prasasti, notulen rapat, agenda dan sebagainya (Arikunto, 1998:234). Metode ini digunakan untuk melengkapi data yang berhubungan dengan gambaran umum tentang masyarakat Nelayan Meskom Bengkalis.

\section{Sumber Data \\ a. Data primer}

Untuk data primer peneliti akan mendapatkan sumber data dari hasil wawancara dan observasi di lingkungan masyarakat nelayan di Desa Meskom Bengkalis serta Kepala Desa dan aparat desa yang terkait.

\section{b. Data sekunder}

Sedangkan untuk data sekunder akan didapat melalui daftar pustaka yang bersumber dari referensi buku, majalah, ataupun surat kabar dan orang-orang yang dianggap ahli dalam bidang keharmonisan keluarga.

Sedangkan realibilitas secara konsisten memberikan hasil dan jawaban yang sama walau diukur berulang kali. Reabilitas mengandung arti bahwa alat ukur stabil dan dapat diandalkan.

\section{Teknik Analisis Data.}

Teknik analisis data adalah pengolahan data yang diperoleh dengan menggunakan rumus atau aturan-aturan sesuai dengan pendekatan penelitian (Arikunto, 1998:240). Teknik penelitian yang digunakan teknik penelitian Deskriptif kualitatif, Setelah datadata diperoleh, kemudian data dikelompokkan berdasarkan jenis dan sumbernya, penganalisaan data menggunakan metode deskriptif, yaitu menguraikan dengan fakta yang diperoleh kemudian dihubungkan dengan teori yang ada. Data yang telah terkumpul dianalisis setiap waktu secara induktif selama penelitian berlangsung dengan mengolah bahan empirik, supaya dapat disederhanakan ke dalam bentuk yang lebih mudah dibaca, dipahami dan diinterpretasikan. Data diinterpretasikan untuk memperoleh makna dan implikasi hubungan yang ada. Analisis induktif dimulai dengan terlebih dahulu merumuskan sejumlah permasalahan ke dalam beberapa pertanyaan yang dijadikan tujuan penelitian. Beberapa pertanyaan yang menjadi permasalahan utama telah dikemukakan dalam perumusan masalah, akan tetapi pertanyaan-pertanyaan yang lain dapat digali melalui wawancara, atau observasi di lokasi penelitian sehingga dapat mengumpulkan ungkapan kognitif, emosional atau intuisi dari para pelaku yang terlibat.

Data yang ada dirangkum secara deskriptif untuk membantu menemukan konsep-konsep keaslian yang diungkapkan oleh subjek penlitian sendiri sesuai dengan kenyataannya. Dengan cara ini tetap akan dapat menyajikan realitas senyatanya (emik) sebagaimana yang diharapkan dalam penelitian 
kualitatif. Dalam melakukan analisis, diterapkan cara pentahapan, yaitu mereduksi data, memaparkan data empirik, menarik kesimpulan dan memverifikasikan. Mereduksi data dimaksudkan sebagai penyederhanaan, pengabstrakkan dan mentransformasikan data yang masih kasar dari beberapa catatan lapangan. Dengan tahap ini dimaksudkan dapat mengklasifikasikan, mengarahkan, membuang yang tidak perlu hingga dapat mengorganisir data yang sangat diperlukan.

\section{HASIL PENELITIAN}

Berdasarkan hasil peyajian data penelitian yang telah penulis lakukakan sesuai dengan teori self disclosure, dimana Person, Nelson, Titsworth, dan Harter menegaskan bahwa Proses hubungan interpersonal akan semakin dalam dan dekat tergantung dari seberapa intensitasnya keluarga melakukan pengungkapan diri. meski dalam kenyataannya suami/istri akan melakukan reisistensi terhadap informasi yang semakin dibuka dan informasi yang ditampakkan akan semakin pribadi, sensitif, hingga informasi-informasi penting yang hanya suami istri sajalah bisa mengetahuinya (Pearson 2003, 187-188).

Self disclosure merupakan kegiatan memberikan informasi tentang perasaan dan pikiran kepada orang lain yang disampaikan secara verbal dan tindakan. Model yang sesuai dengan hasil analisis diatas adalah Johari Window pada daerah terbuka (open area), dimana Daerah ini berisikan semua informasi, perilaku, sikap, perasaan, keinginan, motivasi, gagasan, dan sebagainya yang diketahui oleh diri sendiri dan suami istri, maka Makin luas diri publik suami istri, maka makin terbuka suami istri pada pasangan, dan makin harmonis hubungan keluarga itu (Rakhmat, 2012:106107).

\section{Efektifitas Komunikasi Interpersoal}

Komunikasi merupakan sebuah sarana yang sangat efektif dilakukan untuk mewujudkan keharmonisan dalam kehidupan keluarga. Setiap orang punya keinginan yang kuat untuk mecapai cita-cita luhur yaitu mencapai kehidupan yang sejahtera dunia dan akhirat, sebagaimana tujuan sebuah rumah tangga yaitu menjadi keluarga yang sakinah mawaddah warrahmah.

Untuk mecapai cita-cita luhur sebuah keluarga, masyarakat nelayan di desa Meskom berusaha meciptakan sebuah komuikasi dalam kehidupan keluarganya yaitu antara suami,isteri dan anak-anak. Menurut Pak Sufendi sebagai kepala Desa Meskom meyatakan bahwa kehidupan keluarga di desa Meskom sampai saat ini berlangsung dengan baik. Jarang sekali terjadi perselisihan dalam kehidupan rumah tangga meraka. Terjalin sebuah komunikasi interpersoal diantara mereka baik suami dan isteri serta dengan anak-anak mereka, walaupun kehidupan mereka secara ekonomi paspasan. Dikatakan paspasan karena pengahsilan seorang nelayan sangat tergantung dengan hasil tangkapan ikan dan hasil tangkapan itu tidak bisa diukur atau diperkirakan. Hasil kerjanya berbeda dengan profesi lainnya seperti seorang karyawan pabrik atau pegawai negeri atau seorang petani atau peternak yang hasilnya bisa diperkirakan.

Seorang nelayan pulang dari laut tidak selalu membawa hasil yang memuaskan, kadang mendapat hasil ikan yang banyak, kadang-kadang mendapat hasil tangkapan sedikit, bahkan kadang-kadang tidak dapat ikan sama sekali. Kondisi seperti ini sudah sering mereka alami dan tidak menggoyahkan kehidupan keluarga, mereka hadapi itu semua degan sabar dan tawakkal kepada Allah.

Tantangan kehidupan masyarakat nelayan secara ekonomi boleh dikatakan menengah kebawah. Kondisi ekonomi ini harus disadari oleh mareka para keluarga nelayan sehingga mereka siap mental, tidak menuntut begitu banyak atau terlalu konsumtif, tidak terlalu banyak pengeluaran belanja yang dianggap kurang perlu. Inilah kenyataanya 
yang ada pada masyarakat nelayan Meskom menurut pak Sufendi (sebagai kepada Desa) mereka menerapkan hidup sederhana. Kesederhanaan ini menimbulkan rasa nyaman dalam kehidupan masing-masing keluarga nelayan, tidak terjadi gejolak-gejolak dalam keluarga.

Menurut pak Burhan sebagai seorang nelayan, ketika kita tanyakan bagaimana bentuk komunikasi dalam kehidupan sehari-hari dalam keluarga. Bisalah kita orang kampung dengan keluarga selalu tukar pikiran dengan berbualbual antara suami dan isteri. Banyak hal yang dibicangkan dengan isteri terutama sekali dengan kondisi ekonomi keluarga nelayan kadang senang kadang susah sangat tergantung dengan hasil tangkapan ikan. Kami belum merasa hasil yang memuaskan karena kapal yang gunakan masih menyewa, jadi berapa saja yang diperoleh dari hasil tangkapan dibagi dengan pemilik kapal. Berbeda dengan kawankawan lainya yang sudah punya kapal sendiri mungkin hasilnya lumayanlah karena sudah tidak dibagi lagi. Kalau seperti saya yang masih menyewa kapal harus prihatin dulu. Sangat ingin sekali memiliki kapal sendiri namun belum terwujud, mudah-mudahan Allah memberikan jalan untuk bisa membeli kapal sendiri. Walaupun kondisi seperti itu saya dan isteri sangat bersyukur sekali sudah memiliki tanah dan rumah sendiri. Selanjutnya kami memikirkan perkembangan anak-anak, pendidikan dan masa depan mereka. Kami berharap mereka mendapatkan pendidikan yang lebih tinggi.

Waktu yang dipergunakan untuk berkomunikasi dengan keluarga adalah ketika tidak ke laut. Jika pergi laut siang hari bercengkerama dengan keluarga malam hari kalau pergi ke laut malam hari maka bercengkerama dengan keluarga siang hari. Kita pakai waktu santai-santai dengan keluarga kalau tidak pergi ke laut, seperti yang bapak tengok kami duduk santai didepan rumah sambil bercerita ria dengan isteri dan anak-anak bermain-main pula dekat kito. Jadi terasa terobati kelelahan kita setelah pulang dari laut hidup damai dengan keluarg. Biasanya kami santai dengan keluarga diteras rumah sambil bercerita dan bersenda gurau, banyak hal-hal dalam kehidupan keluarga yang harus kami bahas bersama-sama terutama sekali masa depan keluarga bahagia dunia dan akhirat atau keluarga sakinah mawaddah warrahmah.

Menurut pak Ismail, kadang kita dari laut membawa hasil yang banyak dan kadang sedikit bahkan ade kadang tak dapat ikan sama sekali, inilah yang kami rasakan sebagai seorang nelayan, namun kita suami isteri tetap sabar dan senyum. Tak perlu marah walau pulang tidak membawa ikan dan tak perlu bersuka ria sangat kalau pulang membawa ikan yang banyak. Bahasa kami dapat tak dapat ikan itulah baru rezki yang diberi oleh Allah Swt, maka kami mensyukurinya mudah-mudahan Allah tetap memberi rezki yang banyak. Kami saling membina keharmonisan dengan saling berdiskusi dan bertukar pikiran antara suami isteri dan juga anak-anak

Menurut Pak Darwis sebagai seorang nelayan tetap melakukan komunikasi dalam kehidupan keluarga, terutama sekali suami isteri dan juga anak-anak. Bentuk komunikasi yang sering kami lakukan adalah dengan saling bertukar pikiran membahas hal-hal yang behubungan dengan kehidupan sehari-hari.

Waktu yang dipergunakan untuk melakukan komunikasi dengan keluarga menurut pak Darwis adalah ketika tidak pergi kelaut. Waktu yang dipergunakan untuk pergi melaut kadang pagi sampai sore hari dan juga kadang-kadang malam sampai shubuh. Diluar waktu tidak kelaut ini dipergunakan bercengkerama dengan keluarga isteri dan anak, memberikan pandangan pada anak-anak akan pahit manisnya sebuah kehidupan. Tempat yang sering kami pergunakan untuk berkomunikasi dengan keluarga biasanya sewaktu makan bersama dengan isteri dan anak-anak didapur rumah, kemudian sambil 
santai nonton tv dan juga waktu sore hari sambil duduk teras rumah dan teras jembatan rumah.

Menurut Pak Jumhur, sebagai nelayan senang susah itu biasa kami alami namun tetap kami hadapi dengan sabar. Kadang Allah member kita rezki yang banyak kadang pula sedikit dan itu harus kita terima dengan senanng hati. Seorang isteri tidak perlu cemberut ketika suami pulang dari laut dengan membawa rezki ikan yang yang sedikit dan tidak pula bersorak sorai kita suami pulang dengan membawa ikan yang banyak. Suami isteri dan juga anak-anak sudah sering membicarakan kondisi-kondisi yang dialami tersebut, dengan begitu kehidupan keluarga menjadi damai.

Kami selalu berdiskusi dengan isteri dan anak-anak diwaktu-waktu santai dan sambil makan malam. Bersenda gurau sambil menghilangkan lelah setelah pulang dari malaut. Banyak hal yang bisa dibicarakan ketika bersama dengan isteri, disitulah waktu untuk masing-masing pasangan suami isteri mencurahkan kasih sayangnya senang susah ditanggung bersama.

\section{Keharmonisan Keluarga}

Menurut Pak Efendi kepala Desa Meskom, Kehidupan masyarakat nelayan didesa Meskom masih sangat sederahana. Mereka menangkap ikan masih memepergunakan kapal pompong dan jaring biasa, ada pompong yang milik sendiri dan ada yang menyewa. Inilah kondisi yang mereka alami. Walaupun seperti itu mereka tetap berjuang untuk mewujudkan sebuah keluarga yang harmonis.

Menurut Pak Darwis sebagai seorang nelayan untuk memperjuangkan keharmonisan keluarga, kami suami isteri harus saling mengerti dengan kesulitan, kebiasaan dan kesukaan masing-masing. Suami yang berangkat kelaut siang hari berpanas-panas ditengah laut melempar jaring kelaut dan menarik jaring lagi apakah ada ikan yang terjaring atau tidak, diulang berkali-kali sampai waktu sore hari kemudian pulang kerumah. Isteri dirumah menyiapkan segala perlengkapan bekal suami berangkat kelaut dan meyiapkan anak-anak untuk sekolah, menuggu suami pulang dengan menyajikan masakan kesukaan suami. Masing-msing sudah mengerti dan memahami kebiasaan yang setiap hari dilakukan. Kami saling menerima kelebihan dan kekurangan masing-masing

Kelebihan dan kekurangan diantara suami isteri dijadikan motivasi dan instopeksi diri untuk kemudian saling melengkap dan tidak saling meyalahkan. Menurut pak Darwis bahkan kita harus saling menghargai kemampuan masing-masing dalam mewujudkan keharmonisana keluarga, suami tangkas dilaut dan isteri tangkas dirumah. Sehingga timbul kepercayaan diantara kami suami isteri, ketika suami kelaut isteri dirumah tidak berjalan-jalan kemana-mana tanpa sepengetahuan suami, justru isteri harus mendoakan suami supaya pulang dengan selamat dan membawa hasil tangkapan ikan yang banyak. Sikap saling mempercayai ini akan menimbulkan rasa kasih sayang yang sangat mendalam diantara pasangan suami dan isteri.

Menurut Pak Jamhur sebagai seorang mantan nelayan, Dengan kondisi yang sering dialami oleh masyarakat nelayan baik senang maupun susah, namun kami dalam kehidupan rumah tangga tetap saling menghargai dan mempercayaai masing-masing bahkan saling mencintai. Kami sudah memahami kebiasaan yang sering dilakukan dalam kehidupan keluarga, tidak ada rasa sangsi ketika isteri atau suami keluar rumah. Ketika isteri atau suami sedang tidak ada dirumah, berarti sedang ada keperluan lain, atau pergi silaturrahmi kekeluarga terdekat atau ketetangga. Sudah menjadi kebiasaan pada kami untuk berpikir positip, jarang sekali berpikiran negatif atau bahkan berperangsangka buruk pada masingmasingnya. 
Kepercayaan penuh pada masingmasing pasangan dimasyarakat nelayan ini menurut pak Jumhur karena merasa senasib sepenanggungan, dalam tradisi melayu ada petuah " berat sama dipikul dan ringan dijinjing”. Jadi dalam tradisi melayu masing orang dalam keluarga saling bantu membanrtu satu sama lainnya terutama sekali dalam satu keluarga. Anak sulung (tertua) akan menjadi pendukung keluarga yang akan membantu orangtuanya dalam kehidupan keluarga. Tumbuh sikap saling menghormati, menghargai dan munculnya rasa kasih sayang diantara sesama anggota keluarga.

Sekarang saya dah tak kelaut lagi anakanak sudah keluarga semua ada yang di Kota Dumai, Pekanbaru, Kalimantan dan ada yang masih tetap di Meskom Bengkalis. Saya keliling mengungjungi anak-cucu yang diluar Bengkalis. Mensyukuri dan menikmati hari tua sebagai mantan nelayan.

Menurut pak Burhan sebagai seorang nelayan untuk memperjuangkan keharmonisan keluarga, kami suami isteri harus saling mengerti dengan kesulitan, kebiasaan dan kesukaan masing-masing. Tugas seorang suami keahliannya sebagai nelayan kalau pergi berangkat kelaut siang hari berpanas-panas ditengah laut melempar jaring kelaut dan menarik jaring lagi apakah ada ikan yang terjaring atau tidak, diulang berkali-kali sampai waktu sore hari kemudian pulang kerumah. Jika pergi sore sampai malam dan pulang pagi, maka kami berembun ditengah laut kadang kadang berhujan-hujan ditengah laut dan juga berhadapan dengan gelombang kadang bersar dan kadang kecil. Melempar jaring untuk menangkap ikan harus punya keahlian, artinya mengerti dengan kondisi laut apakah dangkal atau laut ini dalam. Pengetahuan tentang kedalaman atau kedangkalan luat ini untuk mengukur batas jaring yang kita miliki. Kita harus berhati-hati jika laut itu dangkal takut jaring kita terkena batu karang sehingga jaring kita bisa rusak. Juga kita harus mengerti dengan jalur yang selalu dilalui oleh-kapal, jangan kita melempar jaring di jalur tersebut karena jaring bisa terkena kipas kapal atau kita akan sibuk menarik jaring. Inilah kegiatan yangkami lakukan selama malaut kadang pulang dengan membawa ikan yang banyak dan kadang dapat sedikit dan kadang tak dapat.Kondisi seperti ini sudah dipahami, ketahui oleh isteri dan anakanak dirumah, bahwa pekerjaan seorang nelayan di laut itu sangat berat.

Isteri dirumah menyiapkan segala perlengkapan bekal suami berangkat kelaut dan meyiapkan anak-anak untuk sekolah, menuggu suami pulang dengan menyajikan masakan kesukaan suami. Masing-msing sudah mengerti dan memahami kebiasaan yang setiap hari dilakukan. Kami saling menerima kelebihan dan kekurangan masing-masing

Kelebihan dan kekurangan diantara suami isteri dijadikan motivasi dan instopeksi diri untuk kemudian saling melengkap dan tidak saling meyalahkan. Menurut pak Burhan bahkan kita harus saling menghargai kemampuan masing-masing dalam mewujudkan keharmonisana keluarga, suami tangkas dilaut dan isteri tangkas dirumah. Sehingga timbul kepercayaan diantara kami suami isteri, ketika suami kelaut isteri dirumah tidak berjalan-jalan kemana-mana tanpa sepengetahuan suami, justru isteri harus mendoakan suami supaya pulang dengan selamat dan membawa hasil tangkapan ikan yang banyak. Sikap saling mempercayai ini akan menimbulkan rasa kasih sayang yang sangat mendalam diantara pasangan suami dan isteri .

Menurut pak Ismail sebagai seorang nelayan, Dengan kondisi yang sering dialami oleh masyarakat nelayan baik senang maupun susah, namun kami dalam kehidupan rumah tangga tetap saling menghargai dan mempercayaai masing-masing bahkan saling mencintai. Kami sudah memahami kebiasaan yang sering dilakukan dalam kehidupan keluarga, tidak ada rasa sangsi ketika isteri atau 
suami keluar rumah. Ketika isteri atau suami sedang tidak ada dirumah, berarti sedang ada keperluan lain, atau pergi silaturrahmi kekeluarga terdekat atau ketetangga. Sudah menjadi kebiasaan pada kami untuk berpikir positip, jarang sekali berpikiran negatif atau bahkan berperangsangka buruk pada masingmasingnya.

Kepercayaan penuh pada masingmasing pasangan dimasyarakat nelayan ini menurut pak Ismail karena merasa senasib sepenanggungan, Artinya segala tugas dan kewajiban yang ada dalam keluarga ditanggung bersama oleh anggota keluarga. Saling bantu membantu dalam keluarga memang sudah kami taradisikan dan harus kami wariskan kepada anak cucu. Sehingga terbentuknya suasana nyaman dan harmonis. Jadi dalam tradisi melayu masing orang dalam keluarga saling bantu membanrtu satu sama lainnya terutama sekali dalam satu keluarga. Anak sulung (tertua) akan menjadi pendukung keluarga yang akan membantu orangtuanya dalam kehidupan keluarga.

\section{SIMPULAN}

Untuk mewujudkan keharmonisan dalam kehidupan keluarga, masyarakat nelayan di desa Meskom berusaha meciptakan sebuah komuikasi dalam kehidupan keluarganya yaitu antara suami,isteri dan anak-anak.

Adanya kepercayaan penuh pada masing-masing pasangan di masyarakat nelayan ini karena merasa merasa senasib sepenanggungan. Dalam tradisi Melayu ada petuah "berat sama dipikul dan ringan dijinjing”. Dalam tradisi Melayu masing orang dalam keluarga saling bantu membantu satu sama lainnya terutama dalam satu keluarga.

Sikap saling menghormati, menghargai dan rasa kasih sayang diantara keluarga nelayan sudah ditanamkan kepada seluruh anggota suami isteri juga anak-anak sejak dini.

\section{DAFTAR PUSTAKA}

Arikunto, Suharsimi. (1998). Prosedur Penelitian Suatu Pendekatan Praktek. Jakarta: Rineka Cipta

Aw, Suranto (2011). Komunikasi Interepersonal. Yogyakarta:Graha Ilmu

Budyatna dan Ganiem (2011). Teori Komunikasi Antar Pribadi. Jakarta: Kencana.

Devito J.A. (1996). komunikasi antarpribadi. Jakarta : Harpercollins Publhiser

Gunarsa. (2002). Asas-asas Psikologi Keluarga Idaman. Jakarta: PT. BPK Gunung Mulia.

Hurlock. (1980). Psikologi Perkembangan. Edisi ke-5 Jakarta : PT Erlangga..

Kriyantono, R. S.sos, M.si. (2010). Teknik Praktis Riset Komunikasi. Jakarta : Kencana

Lestari. (2012). Psikologi Keluarga. Yogyakarta: Kencana.

Mulyana, Deddy (2000). Human Communication.(2) Bandung: PT. Remaja Rosdakarya

Mulyana, Deddy (2000). Human Communication.(1) Bandung: PT. Remaja Rosdakarya

P B, Triton. (2006). SPSS 13.0 Terapan. Yogyakarta: C.V Andi Offset

Poerwandari, E.K. (2007). Pendekatan Kualitatif Untuk Penelitian Perilaku Manusia. Jakarta : Lembaga Pengembangan Sarana Pengukuran dan Pendidikan Psikologi (LPSP3) Fakultas Psikologi Universitas Indonesia.

Qoimi, Ali. (2002). Menggapai Langit Masa Depan Anak. Bogor : Cahaya

Qoriah (2005). Hubungan Kecerdasan Spiritual dengan Keharonisan Keluarga (SuamiIstri). Jurnal. Fakultas psikologi Universitas Islam Negri Maulana Malik Ibrahim Malang.

Rahmat. (1992). Psikologi Komunikasi. Bandung .PT Remaja Rosdakarya. 
Rubani, M (2011). Psikologi Komunikasi.

Pekanbaru. CV. Witra Irzani.

Sadzili, Karim (2012). Bahasa Cinta Suami Istri. Jakarta: Pustaka Al-kausar

Subhan, Zaitunah. (2004). Membangun Keluarga Sakinah. Yogyakarta: Pestaka Pesantren.

Sugiyono, Prof. Dr. (2011). Metode Penelitian Kuantitatif dan Kualitatif dan $R \& D$. Bandung: Alfabeta

Tribunpekanbaru.com, agustus 2013.

Republika Selasa, 24 Jan 2012.

West. R dan Turner L.H. (2008). Teori Komunikasi Edisi 3. Jakarta: Salemba Humanika 